\title{
Cultural Intelligence: A New Zealand Perspective
}

by Judith Bright

I was asked to bring a New Zealand perspective to this cultural intelligence discussion. I gave a paper on a New Zealand Māori perspective some eight years ago, so thought that I would see how that aligned alongside the concept of "cultural intelligence". I have been unable to find any academic writing that critiques cultural intelligence alongside biculturalism, so my experiences in this area will have to suffice.

I am taking as my definition of cultural intelligence, the ability to recognize the impact of, and adapt to differing cultural backgrounds for best results.

New Zealand has a wider issue which impacts on how we, in an Anglican Church library setting might address such issues, because we need to take into account a bicultural layer before we get to a multicultural cultural intelligence discussion. Sir Paul Reeves, former Archbishop of New Zealand said

We talk about biculturalism and there's a Pakeha (ie European) understanding, and then there's a Māori understanding. The Pakeha understanding of biculturalism is being sensitive to Māori issues, and Māori understanding of biculturalism is sharing power where the decisions are made. ${ }^{1}$

This is the bottom line. Māori would expect any library staff not only to have a basic understanding of their culture and how it might impact on customer service, but also to have not made such learning and decisions without them. Cultural intelligence is not enough: a Māori centred approach is the bottom line, with Māori not just being accommodated in the delivery of library services, but involved in designing delivery, and in the management and monitoring of services.

"How can we as Māori get on with it as we see it, not as you from a dominant culture see it, even if you believe that you have an understanding of how we might think about it".

The basis for this is a foundational document for New Zealand, the Treaty of Waitangi, which gave rights to Māori as a condition of European or Pakeha settlement, and which Māori believe have not been adequately honoured.

1 http://anglican.webstation.net.nz/main/biculturalpolicy 
"One of the most challenging aspects of this is to move from the position or perspective of the majority being seen to accommodate other viewpoints and perspectives, to one of developing an appropriate library service together, and empowering others. It is not easy, and requires considerable dialogue, time and understanding."
It is where the decision-making power lies that is the issue. To quote

"the bi-culturalism implicit in a constructive relationship is not the kind that grafts a few multi-cultural bits onto an existing institutional framework. A genuine bi-culturalism acknowledges partner relationship between two equals involving power sharing and distribution of resources" ${ }^{2}$

So what has this meant for our library?

\section{Implications for the John Kinder Theological Library}

\section{Governance}

First of all, and most significantly, it means that right at the policy -making level, we need to involve the Māori sector of our church (and the Pacific sector as well because that is also key). It means that we are obliged to do our best to provide a service which does not disadvantage any one of those groups. It means giving cultural difference full and equal importance in the life of the Church, and therefore in the governance of the library with those partner members of the governing committee.

One of the most challenging aspects of this is to move from the position or perspective of the majority being seen to accommodate other viewpoints and perspectives, to one of developing an appropriate library service together, and empowering others. It is not easy, and requires considerable dialogue, time and understanding.

\section{Kaiwhakamana}

Our experience in providing service to clients from a variety of cultural back grounds, is that the cultural background of a library staff member plays a significant role in their relating to library users, one which no amount of learned cultural intelligence can provide. We are committed to a staff position (Kaiwhakamana) which can only be filled by a person who is Māori. This enables Māori students to have a librarian that they relate to much more easily.

A number of years ago, we had a Tongan librarian for a period. We had a lot of Tongan students. No matter what the student wanted, and no matter whether or not this librarian knew much about the topic under discussion, those Tongan students would always either head straight to him, or wait around until he was available to them.

We often quietly remarked about whether or not the student was getting the information they needed or not, but that was not the point. The point was that that library user felt comfortable being able to voice his request in Tongan, did not feel that he might make a mistake in front of a palangi, and didn't feel that he might unwittingly breach a library protocol or way of doing things.

2 Roger Maaka and Augie Fleras, "Engaging with Indigeneity: Tino Rangitiratanga in Aotearoa," in Political Theory and the Rights of Indigenous Peoples, ed. Duncan Ivison, Paul Patton and Will Sanders (London: Cambridge University Press, 2000), 97. 


\section{"New Zealand}

librarians have

created a Māori

subject headings

thesaurus to

enhance ways of

locating materials in

catalogues. We have

ensured that these

have been added to

all new books and

some retrospective

work has been done."

\section{Refurbishing the library}

This was done in full consultation with our multicultural governance group. Barriers to coming into the library such as a single talk/read space, forbidding grey security gates, was ditched in favour of décor that had Māori and Pacific symbolism, naming, multi spaces with talking and group work catered for, and invisible security gates.

I got into trouble with the size of the Māori wording being smaller than the English.

Access to Māori materials

We have separated out Māori books into a collection that is in an accessible and visible location.

New Zealand librarians have created a Māori subject headings thesaurus to enhance ways of locating materials in catalogues. We have ensured that these have been added to all new books and some retrospective work has been done.

There is also the ever present issue of non-Māori writing about Māori, and for the Pacific, a concern that research about Pacific issues should take place in the Pacific.

There is limited publication in indigenous languages, and almost nothing in theology, which causes us a certain amount of grief. Our role here is to encourage such publishing to start with in-house materials, but the multiplicity especially of pacific languages makes this a big challenge. So far it has been ideas rather than action.

There are issues to do with the formats of academic materials, and the need for more materials in formats that better relate to people who come from an oral rather than print-based culture.

Protocols

There are the protocols in use of materials: karakia (prayers) before moving cultural objects that we are caring for; water available for ritual washing after using taonga or papers perceived as having a significance because of their past.

Summary

So - in summary: all of us who are of European descent, working in this library can work towards enhancing our cultural intelligence in our culturally diverse setting, but just because of who we are we will never fill the same space as anyone from a culture that the library patron represents. We can modify our beliefs, values, attitudes and behaviours and at best can understand, but never be. 